\title{
Cerebellar Ataxia Suspected to Be Caused by Oxytropis glabra Poisoning in Western Mongolian Goats
}

\author{
Shuji TAKEDA ${ }^{1)}$, Hiroyuki TANAKA ${ }^{1)}$, Akinori SHIMADA ${ }^{3) *}$, Takehito MORITA ${ }^{1)}$, Atsushi ISHIHARA ${ }^{2)}$, \\ Altanchimeg ADILBISH ${ }^{4}$, Bayarmunkh DELGERMAA ${ }^{4)}$ and Oyuntsetseg GUNGAA ${ }^{4)}$ \\ ${ }^{1)}$ Department of Veterinary Pathology, Tottori University, Tottori 680-8553, Japan \\ 2) Department of Agricultural Chemistry, Tottori University, Tottori 680-8553, Japan \\ ${ }^{3)}$ Laboratory of Pathology, Azabu University, Sagamihara-shi, Kanagawa 252-5201, Japan \\ 4) Institute of Veterinary Medicine, Zaisan 210153, Ulaanbaatar, Mongolia
}

(Received 10 January 2014/Accepted 11 February 2014/Published online in J-STAGE 27 February 2014)

ABSTRACT. In the last five years in western Mongolia, a neurological disorder and resultant economic loss have developed in goats, sheep, cattle and horses: association of the disease with ingestion of Oxytropis glabra, a toxic plant, was suggested. Affected goats showed neurological signs, including ataxia, incoordination, hind limb paresis, fine head tremor and nystagmus. Three goats, one with moderate clinical signs and the other two with severe clinical signs, were necropsied and examined to describe and characterize the histologic, immunohistochemical and ultrastructural lesions. Although no gross pathological changes were observed in a variety of organs including the central nervous system of these goats, microscopic examination of the cerebellum demonstrated degenerative changes in all these goats, such as vacuolar changes and loss of Purkinje cells, torpedo formation in the granular layer, increased number of spheroids in the cerebellar medulla, and loss of axons and myelin sheaths of Purkinje cells. The chemical analysis of the dried plant detected $0.02-0.05 \%$ (dry weight basis) of swainsonine. This is the first report describing the clinical and pathological findings in Mongolian goats suspected to be affected by $O$. glabra poisoning.

KEY WORDS: cerebellar ataxia, goat, Mongolia, Oxytropis glabra.

doi: 10.1292/jvms.14-0023; J. Vet. Med. Sci. 76(6): 839-846, 2014

Plants belonging to the Oxytropis and Astragalus genera are called locoweeds, because they contain swainsonine, an indolizidine alkaloid of endophyte origin, and poisoning results in characteristic clinical and pathologic changes of locoism [6, 11, 16, 18, 27, 29, 38]. A. mollissimus, A. lentiginosis, $A$. wootoni, $A$. mollissimus, $O$. serica and $O$. lambertii are the locoweeds in North America that commonly poison livestock [6]. A recent study reported that $O$. glabra obtained in Mingqin, Gansu, Pingluo and Ningxia in China contains substantial amounts of swainsonine $(0.008 \%$ : dry weight basis) and is also classified as a locoweed [38]. Swainsonine inhibits lysosomal-mannosidase and Golgi mannosidase II, resulting in cellular vacuolation and degeneration in a variety of organs in multiple body systems including the reproductive, nervous, endocrine and immune systems; cerebral and cerebellar changes are responsible for the neurological signs of the poisoning [8-10, 16, 22, 24, 29, 34].

In the last five years, a neurological disorder and resultant economical loss have developed in goats, sheep, cattle and horses in Zavkhan aimag in western Mongolia; over 3,000 goats, 1,000 sheep, 500 cattle and 200 horses were estimated

*Correspondence to: Shimada, A., Laboratory of Pathology, School of Life and Environmental Science, Azabu University, 1-17-71 Fuchinobe, Sagamihara-shi, Kanagawa 252-5201, Japan. e-mail: a-shimada@azabu-u.ac.jp

(C)2014 The Japanese Society of Veterinary Science

This is an open-access article distributed under the terms of the Creative Commons Attribution Non-Commercial No Derivatives (by-nc-nd) License $<$ http://creativecommons.org/licenses/by-nc-nd/3.0/>. to be affected, and half of the affected animals died. Affected animals showed neurological signs, including ataxia, incoordination, hind limb paresis, fine head tremor and nystagmus. Anecdotes from local veterinarians and farmers suggest a strong association between the ingestion of the plant, $O$. glabra (Fig. 1), and the neurological disorder.

Goats, because of their dietary plasticity and capacity to access preferred and desirable plant species, were a dominant factor causing rangeland degradation; severe drought, combined with the higher goat stocking rate, created con-

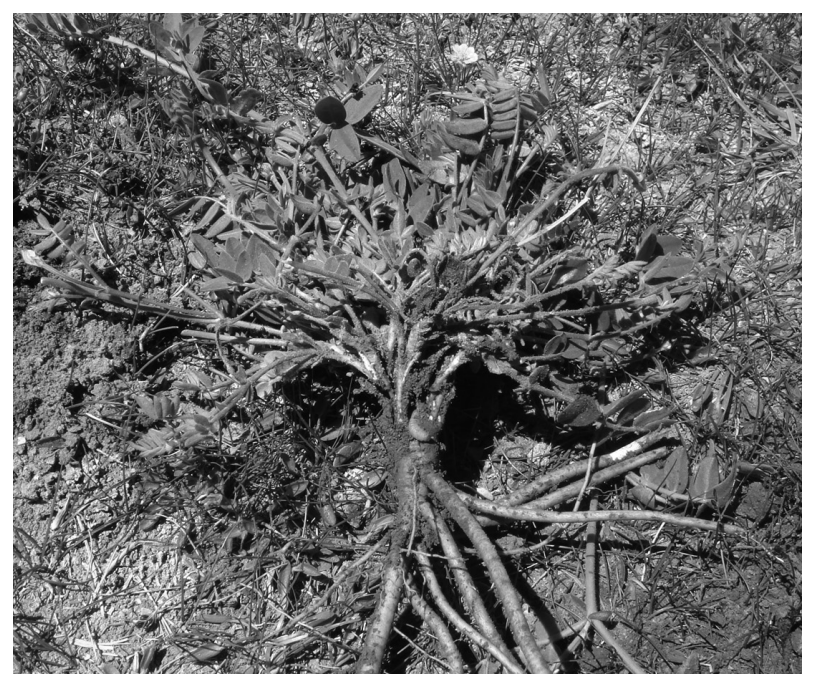

Fig. 1. Oxytropis glabra plant in Summer. 
Table 1. Clinical history of the goats

\begin{tabular}{|c|c|c|c|c|c|}
\hline Goat No. & Age & Sex & $\begin{array}{l}\text { Neurological } \\
\text { signs }\end{array}$ & $\begin{array}{l}\text { Duration of the } \\
\text { illness }\end{array}$ & History of the plant ingestion \\
\hline 1 & 24 months & female & ++ & 1 month & $\begin{array}{l}\text { Grazing for } 2 \text { months in the heavily contaminated } \\
\text { field before the onset of the disease }\end{array}$ \\
\hline 2 & 12 months & female & +++ & 3 weeks & $\begin{array}{l}\text { Grazing for } 2 \text { months in the lightly contaminated } \\
\text { field before the onset of the disease }\end{array}$ \\
\hline 3 & 48 months & female & +++ & 1 month & $\begin{array}{l}\text { Grazing for } 2 \text { months in the heavily contaminated } \\
\text { field before the onset of the disease }\end{array}$ \\
\hline 4 & 24 months & male & - & - & - \\
\hline 5 & 36 months & male & - & - & - \\
\hline
\end{tabular}

ditions causing accelerated loss of ecological condition and rangeland degradation in Mongolia [23]. Vegetation degradation will drive to decreasing pasture yield, which eventually would likely to lead to limiting forage choices for animals and increasing animal poisoning incidents from poisonous plants and losses [7]. Spread of poisonous plants including $O$. glabra is considered to be the serious problem after desertification for China's northwestern grassland regions including Xinjiang, which is next to western Mongolia [39]. Farmers claim that O. glabra continues to increase in the western Mongolian desert areas in Khobd, Zabkhan and Govi- Altai provinces.

The purpose of the present study is to characterize the pathological symptoms of cerebellar ataxia in western Mongolian goats suspected to be caused by poisoning due to $O$. glabra ingestion.

\section{MATERIALS AND METHODS}

Animals: Over 3,000 Kashmir goats having been exposed to plant, O. glabra, in Zavkhan aimag in western Mongolia showed neurological signs, including ataxia, incoordination and hind limb paresis in the last 5 years. Animals taken care to be away from the pasture field contaminated with the plant survived, and half of the affected animals eventually died under the inconvenient environmental conditions including severe climate changes and malnutrition resulting from the shortage of pasture grass. Three affected goats having histories of $O$. glabra ingestion and two goats with no histories of the plant ingestion were obtained for the pathological examination (Table 1). Goat No. 1 (female, 24 months old) and goat No. 3 (female, 48 months old), which belonged to the same flock and were grazed for 2 months since spring in the pasture field heavily contaminated with the plant, showed moderate and severe neurological signs, respectively and moved from the contaminated pasture field since the beginning of the symptoms for 1 month till euthanasia. Goat No. 2 (female, 12 months old) was grazed for 2 months since spring in the pasture field lightly contaminated with the plant, showed severe neurological signs and moved from the contaminated pasture field since the beginning of the symptoms for 3 weeks till euthanasia.Two normal goats (No. 4: male, 24 months old, No. 5: male, 36 months old), which were grazed for 2 months since spring in the pasture field not contaminated with the plant, were used as controls. Blood samples were taken from goat No.1, goat No.3, goat No.4 and goat No.5. The packed cell volume, red blood cell count, total white blood cells count, serum values of glucose, total protein, and albumin and serum activities of gamma glutamyl transferase and aspartate aminotransferase were within normal range. Goats were euthanized and necropsied.

Histopathology: After complete post-mortem examination, the brain and samples of the liver, spleen, kidney, heart, lung, pancreas, thyroid gland, skin, spinal cord, eyes and skeletal muscles were collected, fixed in $10 \%$ neutral phosphatate-buffered formalin and embedded in paraffin. Three-micrometer thick paraffin sections of each organ were cut and stained with hematoxylin and eosin (HE).

Immunohistochemistry of the selected sections from the cerebellum was done by previously reported techniques [36]. Briefly, rabbit polyclonal antibodies to Calbindin $(1: 200$ dilution in PBS)(Cell Signaling Technology, MA, U.S.A.), glial fibrillary acidic protein (GFAP) (1:100 dilution in PBS) (DAKO, Glostrup, Denmark) and mouse monoclonal antibody to 200-kDa neurofilament (RNF404) (1:100 dilution in PBS) (Abcam, Cambridge, U.K.) were used as primary antibodies. The sections were reacted with the biotin-labeled goat anti-rabbit IgG (1:400 dilution in PBS) (DAKO) as the secondary antibody. Positive reactions, resulted in the brown staining with diaminobenzidine, were then counter-stained with hematoxylin.

Lectin histochemistry was performed according to previously described techniques [29]. Briefly, sections from the cerebellum were reacted with Biotinated Lectin Kit I (Vector Laboratories, Burlingame, CA, U.S.A.) including Concanavalin A (Con A) (1:1,600 dilution in PBS), Glycine max (soybean) agglutinin (SBA) (1:1,600 dilution in PBS), Triticum vulgaris (white germ) agglutinin (WGA) (1:800 dilution in PBS), Dolichos biflorus agglutinin (DBA) (1:1,600 dilution in PBS), Ulex europaeus agglutinin 1 (UAE 1) (1:1,600 dilution in PBS), Ricinus communis agglutinin (RCA120) (1:1,600 dilution in PBS) and Arachis hypogaea (peanut) agglutinin (PNA) $(1: 1,600$ dilution in PBS) and followed by avidin-biotin reaction. The positive reactions resulted in brown staining with diaminobenzidine, and the sections were counter-stained with hematoxylin.

For transmission electron microscopy evaluation, $1-\mathrm{mm}^{3}$ duplicate tissue block samples from $10 \%$ neutral 
phosphatate-buffered formalin-fixed wet cerebellar vermis tissues of the affected goats and $2.5 \%$ glutaraldehyde-fixed wet cerebellar vermis tissues of the normal goats were used. Samples were then postfixed in $1.5 \%$ osmium tetroxide, dehydrated via alcohols and propylene oxide and embedded in epon. Semithin and thin sections were stained with $1 \%$ toluidine blue and uranyl acetate/lead citrate, respectively.

Analysis of swainsonine: Plant materials were collected in Zavhan aimag in Mongolia in June of 2010. The swainsonine content of $O$. glabra was measured by liquid chromatography coupled with tandem mass spectrometry (LC-MS/MS) analysis with an amide column using procedures previously described [11]. Briefly, samples (100 mg) of the air-dried plant materials were extracted with methanol, and the solution was subjected to LC-MS/MS analysis. LC separation was performed with a Waters Acquity UPLC (Waters, Milford, MA, U.S.A.) equipped with an Acquity UPLC BEH amide column (2.1 mm i.d., $100 \mathrm{~mm}$ long and $1.7 \mu \mathrm{m}$ particle size, Waters). Concentration of swainsonine was determined by multiple reaction monitoring (MRM). Monitored mass transition was from $m / z 174.2$ to $\mathrm{m} / \mathrm{z} 138.1$. Cone voltage and collision energy were optimized for MRM detection using an authentic swainsonine compound (Wako Pure Chemical Industry, Osaka, Japan).

\section{RESULTS}

Clinical findings: Goat No. 1 showed moderate clinical signs including ataxia, head and neck tremor and sudden falling. Goat No. 2 showed marked clinical signs, including ataxia, hind limb paresis, fine head and neck tremor, incoordination, sudden falling to the side or backward, difficulty to stand and fine nystagmus (Fig. 2). Goat No. 3 also showed marked clinical signs, including ataxia, fine head and neck tremor and hind-limb paresis (Table 1).

Gross pathology: Occasional foci of mild bruise resultant from hind limb paresis were observed in the affected goats; there were no other gross pathological changes.

Histopathology and Immunohistochemistry: The histopathological results of the analysis of the affected goats are summarized in Table 2. Lesions, which have been well demonstrated by Calbindin immunohistochemistry, were

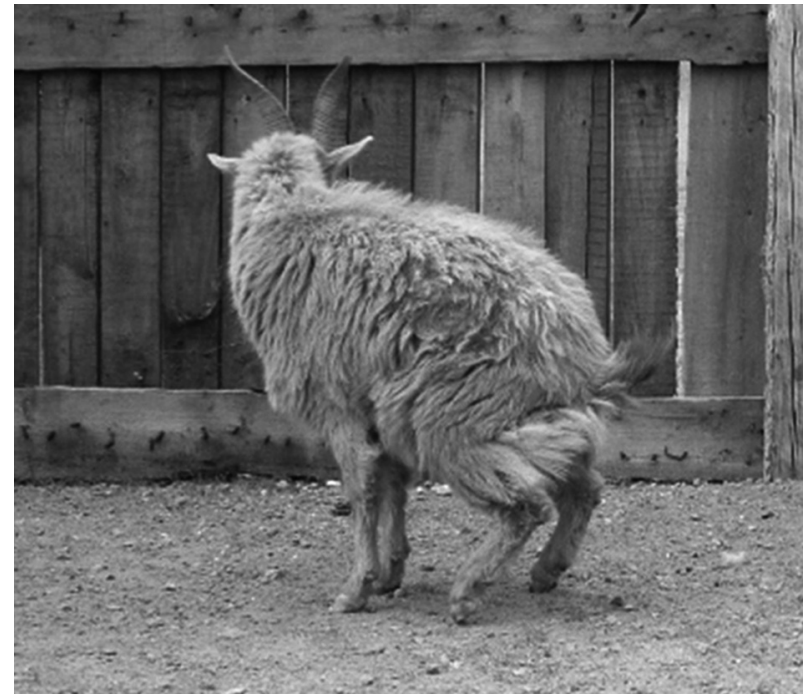

Fig. 2. An affected goat (case No. 3) showing hind-limb paresis.

dominant in the cerebellum and consisted of vacuolar degeneration and loss of Purkinje cells (Fig. 3E and 3I). Cerebellum of goat No. 1 showed marked fine vacuolar degeneration of Purkinje cells (Fig. 3F), predominantly in the cerebellar culmen and declive. Gliosis observed by GFAP immunohistochemistry was associated with these changes. Moreover, a large number of spheroids close to the neuronal bodies were observed in the cerebellar nuclei. Marked gliosis was associated with these changes. The cerebella of goats No. 2 and No. 3 displayed large vacuolar degeneration and loss of Purkinje cells (Fig. 3G, 3H and 3I) that were dominant in some cerebellar lobules (e.g. the tuber, declive, culmen, lobulus and central lobule). A large number of torpedoes (swelling at the proximal part of the axons of Purkinje cells), which showed positivity in RNF404 immunohistochemistry, were observed throughout the granular layer of the cerebellar cortex (Fig. 4). The severe gliosis evidenced by GFAP immunohistochemistry in the cerebellar cortex was associated with these changes (Fig. 5). Loss of the axon and myelin sheaths of Purkinje cells was observed in the whole

Table 2. Histopathological findings of the goats

\begin{tabular}{|c|c|c|c|c|c|c|c|}
\hline \multirow{3}{*}{ Goat No. } & \multicolumn{7}{|c|}{ Histopathological findings } \\
\hline & \multirow{2}{*}{$\begin{array}{l}\text { Purkinje } \\
\text { cell loss }\end{array}$} & \multicolumn{2}{|c|}{ Purkinje cell changes } & \multicolumn{2}{|c|}{ Axonal swelling } & \multicolumn{2}{|c|}{ Gliosis } \\
\hline & & $\begin{array}{l}\text { fine vacuolar } \\
\text { change }\end{array}$ & $\begin{array}{l}\text { large vacuolar } \\
\text { change }\end{array}$ & $\begin{array}{l}\text { Cerebellar } \\
\text { cortex }\end{array}$ & $\begin{array}{l}\text { Cerebellar } \\
\text { medulla }\end{array}$ & $\begin{array}{l}\text { Cerebellar } \\
\text { cortex }\end{array}$ & $\begin{array}{c}\text { Cerebellar } \\
\text { medulla }\end{array}$ \\
\hline 1 & \pm & +++ & - & + & +++ & + & +++ \\
\hline 2 & +++ & + & ++ & ++ & + & +++ & ++ \\
\hline 3 & +++ & + & ++ & +++ & + & +++ & ++ \\
\hline 4 & - & - & - & - & - & - & - \\
\hline 5 & - & - & - & - & - & - & - \\
\hline
\end{tabular}

Goat No. 1-No. 3: affected goats Goat No. 4 and No. 5: control goats. -: No, \pm : Minimal, +: Mild, ++: Moderate, +++ : Severe. Vacuolar degeneration and loss of Purkinje cells, axonal swelling and gliosis were observed in the cerebellum of the affected goats. 

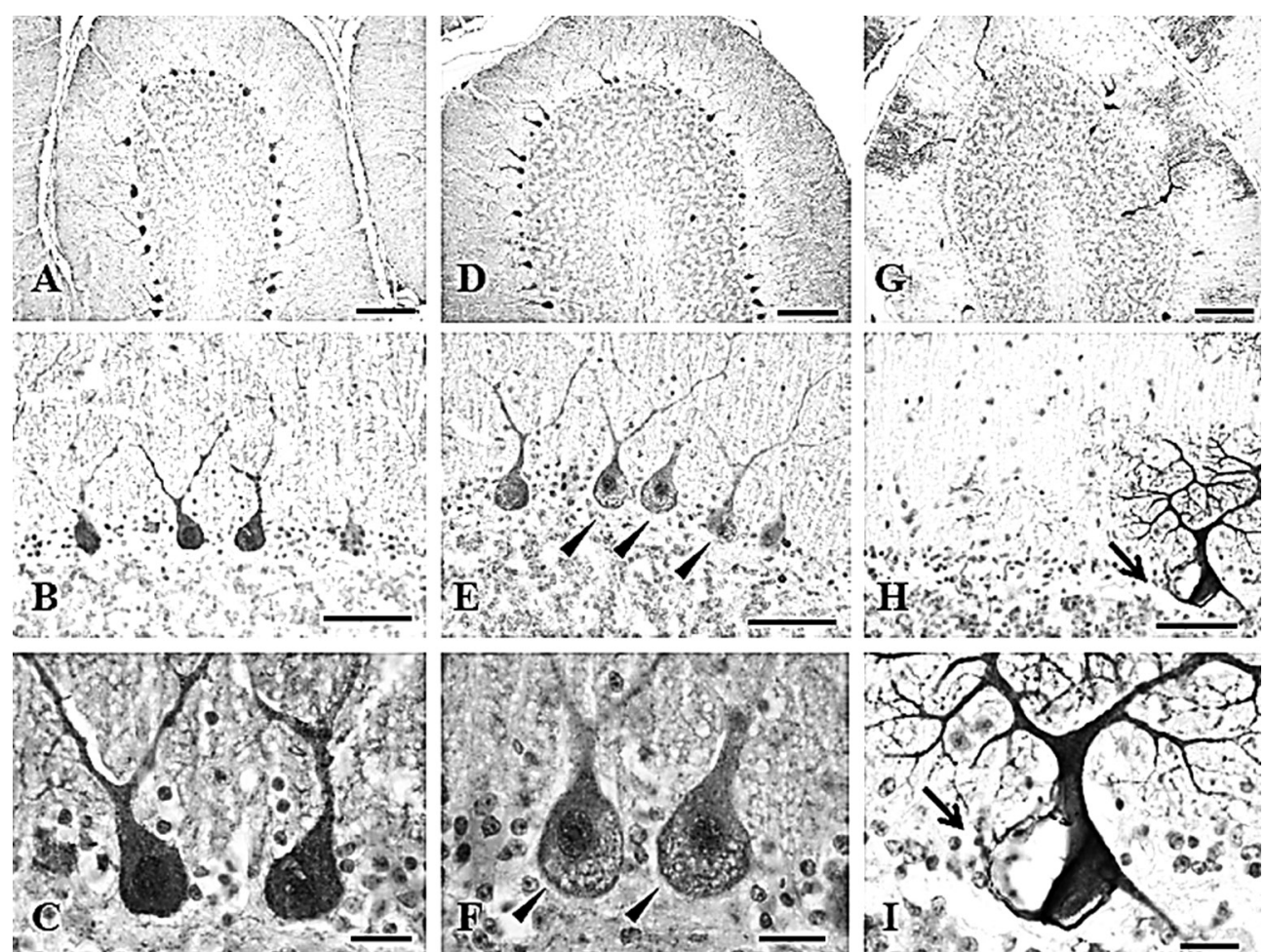

Fig. 3. Cerebellar culmen and declive of control (A, B, C), affected goat No. 1 (D, E, F) and goat No. 3 (G, H, I) showing fine vacuolar degeneration of Purkinje cells (arrowheads) in No. 1 goat (E, F), large vacuolar degeneration (an arrowhead) (H, I) and loss of Purkinje cells $(\mathrm{G}, \mathrm{H})$ in No. 3 goat. Calbindin immunohistochemistry. A, D, G: Bars, $200 \mu \mathrm{m}$. B, E, H: higher magnification of A, D, G, respectively. Bars, $50 \mu \mathrm{m} . \mathrm{C}, \mathrm{F}$, I: higher magnification of $\mathrm{B}, \mathrm{E}, \mathrm{H}$, respectively. Bars, $20 \mu \mathrm{m}$.
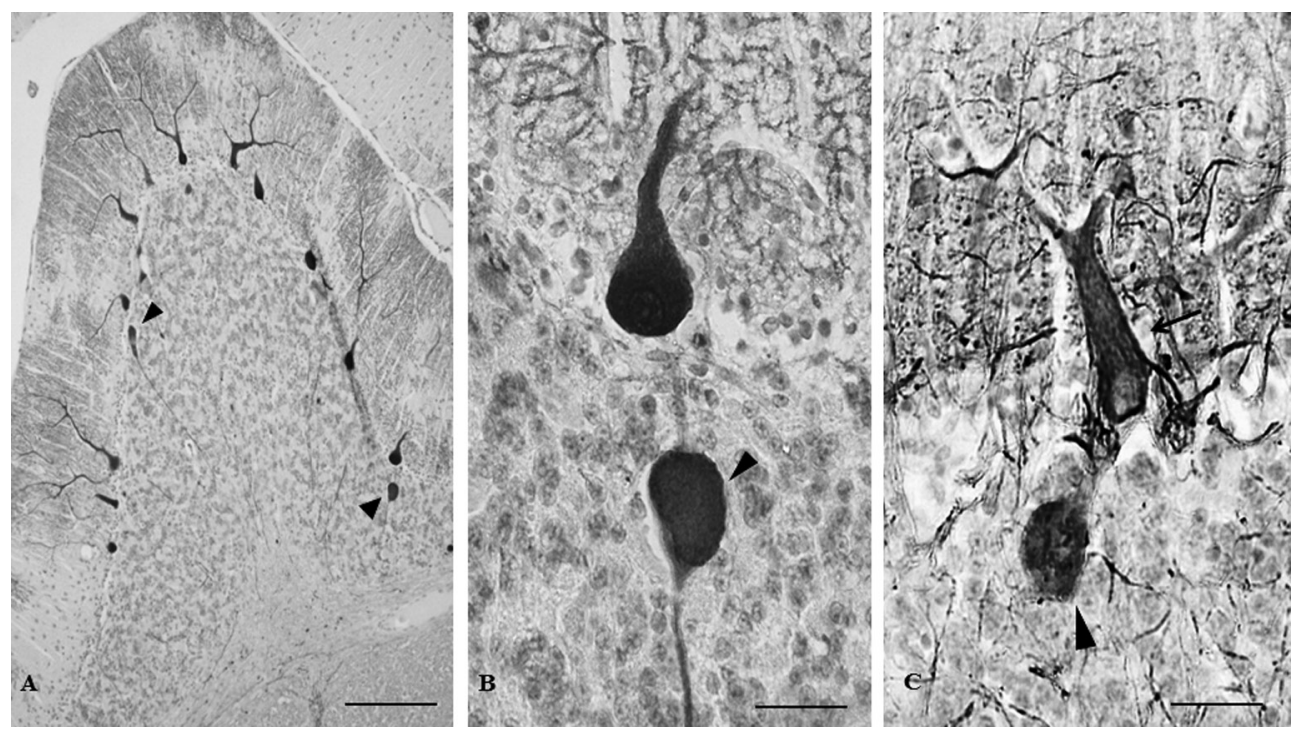

Fig. 4. Cerebellar cortex of affected goat No. 3 showing Purkinje cell loss, axonal degeneration and loss with formation of torpedoes (arrowheads) in the granular layer (A, B, C). The torpedo shows neurofilament positivity (an arrowhead) (C). A, B; Calbindin immunohistochemistry. A: bar, $200 \mu \mathrm{m}$. B: higher magnification of A, bar, $20 \mu \mathrm{m}$. C: neurofilament (RNF404) immunohistochemistry, bar, $20 \mu \mathrm{m}$. 

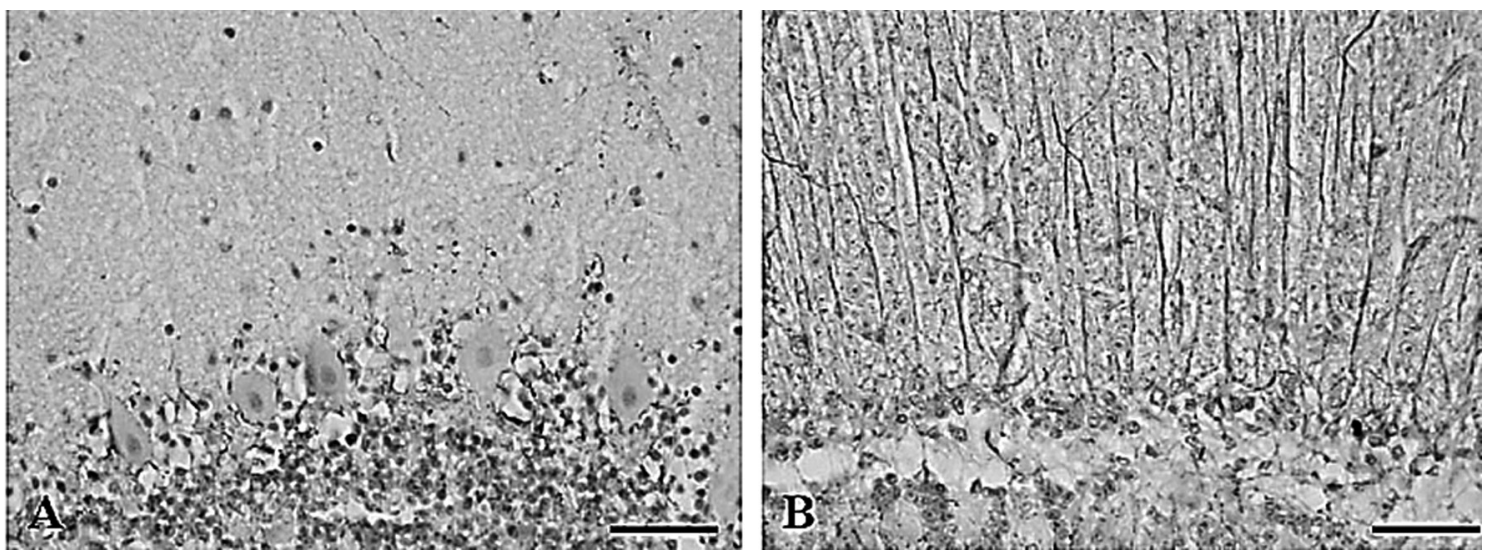

Fig. 5. Cerebellar cortex of control (A) and affected goat No. 2 (B) showing intensively GFAP immunopositive glial fibers in goat No. 2 (B). GFAP immunohistochemistry. Bars, $50 \mu \mathrm{m}$.
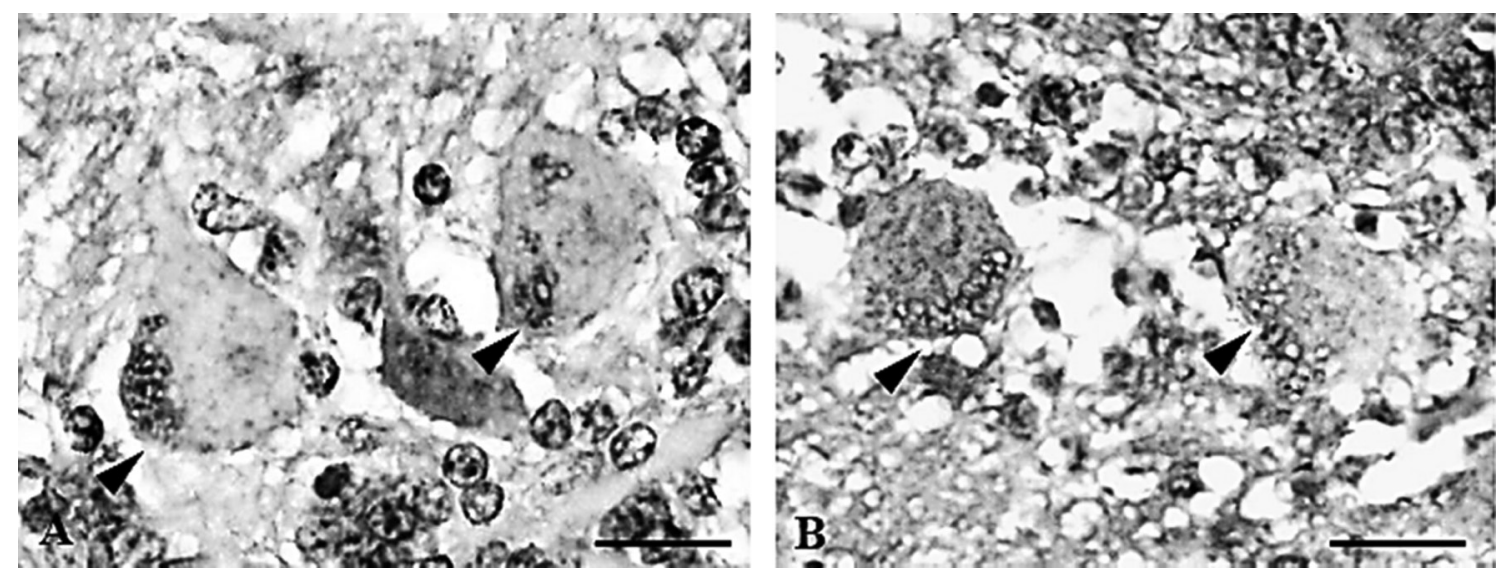

Fig. 6. Purkinje cells of affected goat No. 1 showing Con A (A) and WGA (B) positivity on the vacuolar structures (arrows). Lectin histochemistry. Bars, $20 \mu \mathrm{m}$.

cerebellar medulla where an increased number of glial cells were also noted. No significant changes were observed in the other organs examined.

Lectin histochemistry: While most of the lectin histochemical analysis tested negative, Con A and WGA lectin histochemistry tests showed positive results in the vacuoles of the cerebellar Purkinje cells of the affected goats (Fig. 6).

Electron microscopy: Electron microscopy of the cerebellar Purkinje cells demonstrated a large number of cytoplasmic vacuoles with both straight and curved membranous fragments. Amorphous substances were also observed in these vacuoles (Fig. 7).

Analysis of swainsonine: The concentrations of swainsonine in leaf, stem and root were determined to be 0.0237 , 0.0454 and $0.0484 \%$ (dry weight basis), respectively.

\section{DISCUSSION}

Degeneration and loss of cell bodies and axons of Purkinje cells were observed in the cerebella of goats that were suspected to be affected with $O$. glabra poisoning. These changes in Purkinje cells were well demonstrated by Calbindin immunohistochemistry. Calbindin is one of the calcium binding proteins and is now regarded as a specific marker of Purkinje cells, because of its high expression in Purkinje cells in both normal and degenerative cerebella [36]. These histological changes are in agreement with the neurological signs, such as cerebellar ataxia, incoordination and hind limb tremor. These results suggest that O.glabra ingestion may induce Purkinje cell damage and resultant functional failure of the cerebellum.

Although most lysosomal storage diseases are genetic disorders, some are induced by the ingestion of toxic plants, such as locoweeds (Astragalus and Oxytropis species), in horses and cattle in U.S.A. [13], in horses and sheep in China [39], in sheep [33, 34] in U.S.A., in goat in U.S.A. [25], Swainsona spp. in sheep in Australia [15] and Sida carpinifolia [9] and Turbina cordata [8] in goats in Brazil. All these plants contain swainsonine, one of the major alkaloids found in a large variety of plants [20]. Animals consuming 


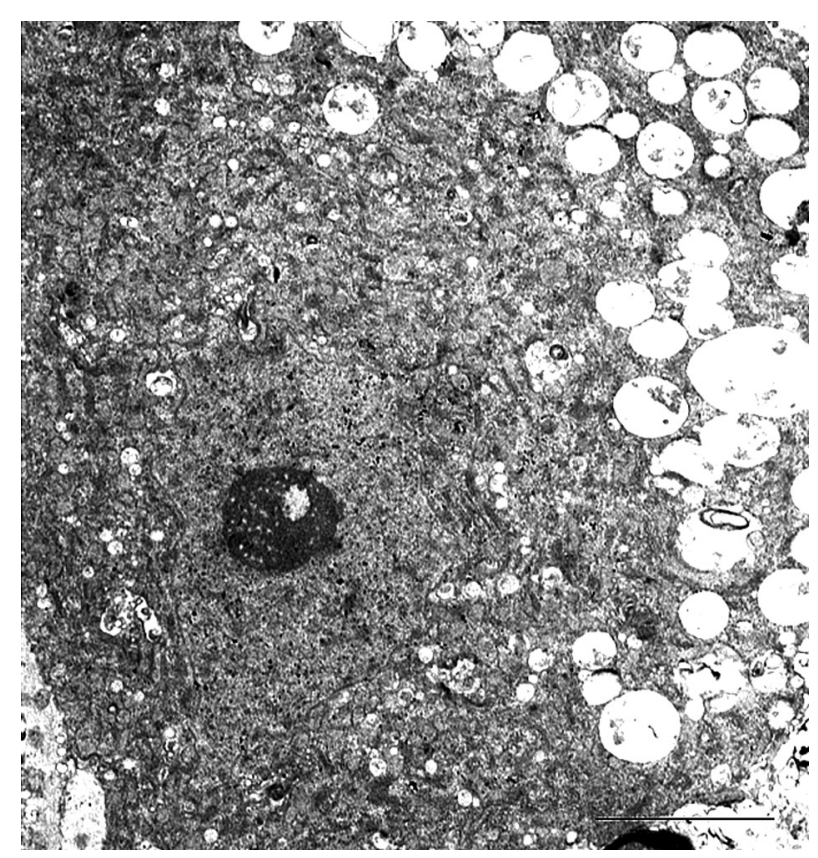

Fig. 7. A cerebellar Purkinje cell of affected goat No. 1 showing a large number of cytoplasmic vacuoles. Straight and curved membranous fragments and amorphous substances are observed in these vacuoles. Bar, $5 \mu \mathrm{m}$.

these plants exhibit symptoms, such as depression, anorexia, rough hair coat, staggering gait, muscle tremors, ataxia, nervousness and abortion, which reflect the dysfunctioning of the nervous system, in particular, as well as of other tissues. From a histological point of view, the cells of the nervous system, including the cerebellum, and other tissues (hepatocytes, pancreatic exocrine cells, thyroid epithelial cells and renal tubular epithelium) display cytoplasmic vacuolar degeneration [20]. Plant poisoning showing cerebellar ataxia in livestock animals is summarized in Table 3. Swainsonine is known to induce a storage disease similar to the genetic mannosidosis as well as a potent inhibitor of lysosomal mannosidase and Golgi mannosidase II. Loss of mannosidase activity ultimately leads to cellular vacuolation and cellular death in a variety of organs, including the cerebrum and cerebellum [30, 31]. Similar to other studies, lectin histochemistry demonstrated Con-A positive findings in the cytoplasmic vacuoles of Purkinje cells of the present goats, suggesting accumulation of mannose rich oligosaccharide material in the vacuoles [24]. These histological changes developed in species-specific tissues and locations [20]. In the present goats, which ingested $O$. glabra from which swainsonine (0.02-0.05\%: dry weight basis) was detected, prominent lesions were observed in the cerebellum; fine vacuolation and loss of Purkinje cells and spheroid formation with gliosis were the dominant features. These changes are different from those in the reported locoweed poisoning in domestic animals; cellular vacuolation was observed in a variety of organs in multiple body systems in addition to the cerebellum [34]. Van Kampen and James [35], however, reported that all but the neurologic lesions resolve within several days of discontinuing locoweed feeding, and neurologic lesions take several weeks to resolve, resulting in fewer Purkinje's cells in the cerebellum in previously poisoned animals. Thus, differences in the histological changes would be, in part, associated with the species of animals, duration of the illness, period of ingestion of the plant and amount of toxin taken $[6,20]$, since swinsonine is quickly cleared from the tissues and vacuolation in the visceral organs quickly resolves when exposure is discontinued [26, 27].

Other toxic plant Ipomea carnea, which contains swainsonine and calystegines, which are nortropanic alkaloid glycosidase inhibitors [12], is known to induce intoxication in livestock animals including goats, sheep and cattle in tropical regions $[1,2,14]$. Clinical and pathological changes are similar to those reported in swainsonine poisoning, but the progression and many of the clinical signs are more severe and progressive [28]. Chronic cases revealed predominantly cerebellar lesions characterized by loss of Purkinje neurons and gliosis of the Purkinje cell layer [14]. In addition, vacuolar changes were mainly observed in the cerebellum and medulla oblongata in the experimentally intoxicated goats; Purkinje cells were the most severely affected cells in the brain [22]. Exact cause of these Ipomoea-associated poisoning and the toxicity of the isolated calystegines has not been identified; contribution of swainsonine than calystegines was suggested [28].

Occurrence of cerebellar ataxia by the other plant poisoning of domestic animals, including sheep, cattle and goats, has been previously reported. The affected animals had similar clinical signs and histopathological features, such as vacuolar degeneration and resultant loss of Purkinje cells

Table 3. Plant poisoning showing cerebellar ataxia in livestock animals

\begin{tabular}{|c|c|c|c|c|}
\hline Plants & Toxins & Clinical findings & Histopathological findings & References \\
\hline $\begin{array}{l}\text { Locoweeds } \\
\text { (Astragalus and Oxytropis species), } \\
\text { Swainsona spp., Sida carpinifolia, } \\
\text { Turbina cordata }\end{array}$ & Swainsonine & $\begin{array}{l}\text { Cerebellar ataxia and } \\
\text { others }\end{array}$ & $\begin{array}{l}\text { Cytoplasmic vacuolar degeneration and loss of } \\
\text { cells in a variety of organs including the cere- } \\
\text { brum, cerebellum, liver, pancreas and kidney. }\end{array}$ & $\begin{array}{l}8,9,13,15,20,25 \\
33,34,39\end{array}$ \\
\hline Ipomea carnea & $\begin{array}{l}\text { Swainsonine } \\
\text { Calystegines }\end{array}$ & $\begin{array}{l}\text { Cerebellar ataxia and } \\
\text { others }\end{array}$ & $\begin{array}{l}\text { Cytoplasmic vacuolar degeneration and loss of } \\
\text { cells in a variety of organs including the cere- } \\
\text { brum, cerebellum, liver, pancreas and kidney. }\end{array}$ & $1,2,12,14,22,28$ \\
\hline Solanum species, Romulea rosea & $\begin{array}{l}\text { Calystegines } \\
\text { suspected }\end{array}$ & Cerebellar ataxia & $\begin{array}{l}\text { Cytoplasmic vacuolar degeneration and loss of } \\
\text { Purkinje cells in the cerebellum }\end{array}$ & $\begin{array}{l}3,4,17,19,21,32 \\
36,37\end{array}$ \\
\hline
\end{tabular}


in the cerebellum $[3,4,17,19,21,32,36,37]$. The main pathologic features were vacuolation, degeneration and loss of Purkinje cells with axonal spheroids in the cerebellar granular layer and white matter. No significant lesions were observed in the other organs [21]. These plant poisonings occurred in goats grazed on Solanum cinereum in Australia [3], sheep grazed on Romulea rosea in Australia [4] and cattle grazed on Solanum bonariense in Uruguay [36, 37], Solanum kwebense in South Africa [32], Solanum dimidiatum in U.S.A. [17, 19] and Solanum fastigiatum var. fastigiatum in Brazil [21]. Out of these plant poisonings with cerebellar ataxia, calystegines were detected in Solanum dimidiatum [19] and in Solanum kwebense [32]. Precise mechanisms of the cerebellar lesions are yet to be studied [32].

As described in other reports on plant poisoning showing cerebellar ataxia in livestock animals, electron microscopy demonstrated membranous fragments and amorphous substances in the membrane-bound cytoplasmic vacuoles in the Purkinje cells of the affected goats [1, 2, 14, 24, 32, 37]. The majority of the vacuoles, however, contained a few membrane fragments and/or a small amount of amorphous substances. The lack of substantial amount of stored material is likely caused by the loss of the oligosaccharides during tissue processing and has been reported in previous studies of swainsonine-induced poisoning [27, 29].

The swainsonine contents of O. glabra were higher than that $(0.008 \%$ : dry weight basis) detected in O. glabra in Inner Mongolia [39] and to the other toxic locoweeds. For example, mean swainsonine concentration ranged from $0.002 \%$ in roots to $0.062 \%$ in leaves of $O$. sericea [5]. Although the threshold of toxicity of swainsonine has not been determined, levels in excess of $0.001 \%$ is assumed to be of concern [19]. Accordingly, it is likely that this toxin is at least one of the toxic principles for the present goats in western Mongolia.

In conclusion, neurological signs, including ataxia, incoordination, hind limb paresis and cerebellar degeneration characterized by vacuolar changes and loss of Purkinje cells were observed in three goats grazed on O. glabra in Mongolia. Swainsonine (0.02-0.05\%: dry weight basis) was detected in the plant. Actual association of the toxic plant with the disease, distribution and growth of the plant and the extent of the problem it presents in Mongolia are to be studied.

ACKNOWLEDGMENTS. The authors received financial support by Special Project (Assessment and Control of Dust Emission in Degraded Drylands of East Asia), MEXT, Japan, for the research, authorship and/or publication of this article, Grants-in-Aid for Scientific Research (S) (KAKENHI) by Japan Society of the Promotion Science (JSPS) and by a research project grant awarded by the Azabu University.

\section{REFERENCES}

1. Armién, A. G., Tokarnia, C. H., Peixoto, P. V. and Frese, K. 2007. Spontaneous and experimental glycoprotein storage disease of goats induced by Ipomoea carnea subsp fistulosa (Convolvula- ceae). Vet. Pathol. 44: 170-184. [Medline] [CrossRef]

2. Armién, A. G., Tokarnia, C. H., Peixot, P. V., Barbosa, J. D. and Frese, K. 2011. Clinical and morphologic changes in ewes and fetuses poisoned by Ipomoea carnea subspecies fistulosa. J. Vet. Diagn. Invest. 23: 221-232. [Medline] [CrossRef]

3. Bourke, C. A. 1997. Cerebellar degeneration in goats grazing Solanum cinereum (Narrawa burr). Aust. Vet. J. 75: 363-365. [Medline] [CrossRef]

4. Bourke, C. A. and Bunker, E. C. 2008. Cerebellar ataxia in sheep grazing pastures infested with Romulea rosea (onion grass or Guildford grass). Aust. Vet. J. 86: 354-356. [Medline] [CrossRef]

5. Cook, D., Gardner, D. R., Ralphs, M. H., Pfister, J. A., Welch, K. D. and Green, B. T. 2009. Swainsonine concentrations and endophyte amounts of undifilum Oxytropis in different plant parts of Oxytropis serica. J. Chem. Ecol. 35: 1272-1278. [Medline] [CrossRef]

6. Cook, D., Ralphs, M. H., Welch, K. D. and Stegelmeier, B. 2009. Locoweed poisoning in livestock. Rangelands 31: 16-21. [CrossRef]

7. Damiran, D. and Darambazar, E. 2003. Toxic Plants of Mongolian Rangelands. Union, Oregon, U.S.A.: Oregon State University, Eastern Oregon Agricultural Research Station.

8. Dantas, A. F. and Riet-Correa, F. 2007. Swainsonine-induced lysosomal storage disease in goats caused by the ingestion of Turbina cordata in northeastern Brazil. Toxicon 49: 111-116. [Medline] [CrossRef]

9. Driemeier, D. and Colodel, E. M. 2000. Lysosomal storage disease caused by Sida carpinifolia poisoning in goats. Vet. Pathol. 37: 153-159. [Medline] [CrossRef]

10. Elbein, A. D., Solf, R., Dorling, P. R. and Vosbeck, K. 1981. Swainsonine an inhibitor of glycoprotein processing. Proc. Natl. Acad. Sci. U.S.A. 78: 7393-7397. [Medline] [CrossRef]

11. Gardner, D.R., Romero, J., Ralphs, M.H. and Creamer, R. 2004. Correlation of an endophytic fungus (Alteraria spp.) with the presence of swainsonine in Labert locoweed (Oxytropis lambertii). pp. 32-37. In: Poisonous Plants and Related Toxins (Acamovic, T., Stewart, C.S. and Pennycott, T.W. eds.), CABI Publishing, Oxford.

12. Haraguchi, M., Gorniak, S. L., Ikeda, K., Minami, Y., Kato, A., Watson, A. A., Nash, R. J., Molyneux, R. J. and Asano, N. 2003. Alkaloidal components in the poisonous plant Ipomoea carnea (Convolvulaceae). J. Agric. Food Chem. 51: 4995-5000. [Medline] [CrossRef]

13. James, L. F., Van Kampen, K. R. and Staker, G. R. 1969. Locoweed (Astragalus lentiginosus) poisoning in cattle and horses. $J$. Am. Vet. Med. Assoc. 155: 525-530. [Medline]

14. de Balogh, K. K., Dimande, A. P., van der Lugt, J. J., Molyneux, R. J., Naudé, T. W. and Welman, W. G. 1999. A lysosomal storage disease induced by Ipomoea carnea in goats in Mozambique. $J$. Vet. Diagn. Invest. 11: 266-273. [Medline] [CrossRef]

15. Laws, L. and Anson, R. B. 1968. Neuronopathy in sheep fed Swainsona luteola and S. galegifolia. Aust. Vet. J. 44: 447-452. [Medline] [CrossRef]

16. McLain-Romero, J., Creame, R., Zepeda, H., Strickland, J. and Bell, G. 2004. The toxicosis of Embellisia fungi from locoweed (Oxytropis lambertii) is similar to locoweed toxicosis in rats. $J$. Anim. Sci. 82: 2169-2174. [Medline]

17. Menzies, J. S., Bridges, C. H. and Bailey, E. M. 1979. Neurological disease of cattle associated with ingestion of Solanum dimidiatum. Southwest. Vet. 32: 45-49.

18. Molyneux, R. J. and James, L. F. 1982. Loco intoxication: indolizidine alkaloids of spotted locoweed (Astragalus lentiginosus). 
Science 216: 190-191. [Medline] [CrossRef]

19. Molyneux, R.J., James, L.F., Ralphs, M.H., Pfister, J.A., Panter, K.E. and Nash, R.J.1994. Polyhydroxy alkaloid glycosidase inhibitors from poisonous plants of global distribution: analysis and identification. pp. 107-112. In: Plant-Associated Toxins. Agricultural, Phytochemical and Ecological Aspects (Colegate, S.M. and Dorling, P.R. eds.), CAB International, Wallingford.

20. Ralphs, M. H. and Stegelmeier, B. L. 2011. Locoweed toxicity, ecology, control, and management. International J. Poison. Plant Res. 1: 47-64.

21. Riet-Correa, F., Mendez, M. D., Schild, A. L., Summers, B. A. and Oliveira, J. A. 1983. Intoxication by Solanum fastigiatum var. fastigiatum as a cause of cerebellar degeneration in cattle. Cornell Vet. 73: 240-256. [Medline]

22. Ríos, E., Cholich, L., Silva, J. and Acosta de Pérez, O. 2008. Histopathological lesions in central nervous system of goats poisoned by Ipomoea carnea. Revista Vet. 19: 130-134.

23. Sheehy, D.P. and Damiran, D. 2012. Assessment of Mongolian rangeland condition and trend (1997-2009). Final report for the World Bank and the Netherlands-Mongolia Trust Fund for Environmental Reform (NEMO).

24. Stegelmeier, B. L., James, L. F., Gardner, D. R., Panter, K. E., Lee, S. T., Ralphs, M. H., Pfister, J. A. and Spraker, T. R. 2005. Locoweed (Oxytropis sericea) induced lesions in mule deer (Odocoileius hemionus). Vet. Pathol. 42: 566-578. [Medline] [CrossRef]

25. Stegelmeier, B. L., James, L. F., Hall, J. O. and Mattix, M. T. 2001. Neurologic disease in range goats associated with Oxytropis sericea (Locoweed) poisoning and water deprivation. Vet. Hum. Toxicol. 43: 302-304. [Medline]

26. Stegelmeier, B. L., James, L. F., Panter, K. E., Gardner, D. R., Ralphs, M. H. and Pfister, J. A. 1998. Tissue swainsonine clearance in sheep chronically poisoned with locoweed (Oxytropis sericea). J. Anim. Sci. 76: 1140-1144. [Medline]

27. Stegelmeier, B. L., James, L. F., Panter, K. E., Ralphs, M. H., Gardner, D. R., Molyneux, R. J. and Pfister, J. A. 1999. The pathogenesis and toxicokinetics of locoweed (Astragalus and Oxytropis spp.) posioning in livestock. J. Nat. Toxins 8: 35-45. [Medline]

28. Stegelmeier, B. L., Molyneux, R. J., Asano, N., Watson, A. A. and Nash, R. J. 2008. The comparative pathology of the glycosidase inhibitors swainsonine, castanospermine, and calystegines A3, B2, and C1 in mice. Toxicol. Pathol. 36: 651-659. [Medline] [CrossRef]

29. Stegelmeier, B. L., Molyneux, R. J., Elbein, A. D. and James,
L. F. 1995. The lesions of locoweed (Astragalus mollissimus), swainsonine, and castanospermine in rats. Vet. Pathol. 32: 289-298. [Medline] [CrossRef]

30. Tulsiani, D. R. P., Broquist, H. P., James, L. F. and Touster, O. 1984. The similar effects of swainsonine and locoweed on tissue glycosidases and oligosaccharides of the pig indicate that the alkaloid is the principle toxin responsible for the induction of locoism. Arch. Biochem. Biophys. 232: 76-85. [Medline] [CrossRef]

31. Tulsiani, D. R. P., Broquist, H. P., James, L. F. and Touster, O. 1988. Production of hybrid glycoproteins and accumulation of oligosaccharides in the brain of sheep and pigs administered swainsonine or locoweed. Arch. Biochem. Biophys. 264: 607617. [Medline] [CrossRef]

32. van der Lugt, J. J., Bastianello, S. S., Ederen, A. M. and van Wilpe, E. 2010. Cerebellar cortical degeneration in cattle caused by Solanum kwebense. Vet. J. 185: 225-227. [Medline] [CrossRef]

33. Van Kampen, K. R. and James, L. F. 1969. Pathology of locoweed poisoning in sheep. Pathol. Vet. 6: 413-423. [Medline]

34. Van Kampen, K. R. and James, L. F. 1970. Pathology of locoweed (Astragalus lentiginosus) poisoning in sheep. Sequential development of cytoplasmic vacuolation in tissues. Pathol. Vet. 7: 503-508. [Medline] [CrossRef]

35. Van Kampen, K. R. and James, L. F. 1972. Sequential development of the lesions in locoweed poisoning. Clin. Toxicol. 5: 575-580. [Medline] [CrossRef]

36. Verdes, J. M., Moraña, J. A., Battes, D., Gutiérrez, F., Guerrero, F., Goicoa, A., Fidalgo, L. E., Barbeito, C. G., Zanuzzi, C. N., Portiansky, E. L. and Gimeno, E. J. 2010. Calbindin D28k expression and the absence of apoptosis in the cerebellum of Solanum bonariense L-intoxicated bovines. Vet. Pathol. 47: 569-572. [Medline] [CrossRef]

37. Verdes, J. M., Moraña, A., Gutierrez, F., Battes, D., Fidalgo, L. E. and Guerrero, F. 2006. Cerebellar degeneration in cattle grazing Solanum bonariense ("Naranjillo") in western Uruguay. $J$. Vet. Diagn. Invest. 18: 299-303. [Medline] [CrossRef]

38. Yu, Y., Zhao, Q., Wang, J., Wang, J., Wang, Y., Song, Y., Geng, G. and Li, Q. 2010. Swainsonine-producing fungal endophytes from major locoweed species in China. Toxicon 56: 330-338. [Medline] [CrossRef]

39. Zhao, M. L., Gao, X. and Han, B. 2011. Locoweed poisoning in the native grassland of China. International J. Poison. Plant Res. 1: 41-46. 